\title{
Rarity Status and Habitat of Shorea laevis and Shorea leprosula in Muara Teweh, Central Kalimantan
}

\section{Sri Wilarso Budi*, Iskandar Zulkarnaen Siregar, Ulfah Juniarti Siregar, Andi Sukendro, Prijanto Pamoengkas, and Tedi Yunanto}

Department of Silviculture, Faculty of Forestry, Bogor Agricultural University, Academic Ring Road Campus IPB Dramaga, PO Box 168, Bogor 16680, Indonesia

Received December 5, 2011/Accepted May 14, 2012

\begin{abstract}
Forest exploitation and conversion to other landuse may cause lost of biodiversity, including most important dipterocarp trees species, i.e. Shorea leprosula and Shorea laevis. The objective of this study was to determine the rarity status of the two important shorea species, i.e. S. laevis and S. leprosula, based on IUCN criteria, their habitat characteristics, and their association with other species, as one of the basis for determining their conservation strategy as a part of forest management. This study was conducted in three types of ecosystem (virgin forest, secondary forest, and fragmented forest) in Muara Teweh, Central Kalimantan. Methodology used in this research includes vegetation and tree diversity analysis. Study results showed that both S. laevis and S. leprosula were included within category of "low risk" in the 3 types of ecosystem in the forest area being studied. Habitat characteristics which determined the absence of S. laevis in the virgin forest habitat was the soil permeability which was too low, whereas other soil chemical and physical properties in the three types of ecosystems were relatively similar. Presence of $S$. laevis were positively associated with species of $S$. uliginosa, Dialium platysepalum, Dipterocarpus ibmalatus, Palaquium rostatum, Vatica rasak, Adinandra sp., and Memecyclon steenis. On the other hand, S. leprosula were positively correlated with S. kunstleri, Castanopsis sp., Shorea sp., Quercus bennettii, Castanopsis argentea, and D. hasseltii.
\end{abstract}

Keywords: threatened species, Shorea spp., habitat characteristic, ecosystems type, associated species

*Correspondence author, email: wilarso62@yahoo.com, telp.+62-251-8626806, fax. +62-251-8626886

\section{Introduction}

Indonesia has over 120 million ha of natural forests. These represent a tenth of the world's remaining tropical rain forests and are among the most biologically diverse in the world, which is mainly dominated by family members of dipterocarpaceae (Sukardjo et al. 1990). The number of species from dipterocarpaceae family in Indonesia is $62 \%$ (238 species) of the whole numbers found in Malay area (386 species) (Purwaningsih 2004). Distribution of dipterocarpaceae is mainly in Sumatera and Kalimantan islands and the more eastern the area is, the less diversity is found (Ashton 1982).

Dipterocarpaceae forest has high ecological, economical, and social functions. However, continuing forest exploitation, forest conversion to other land-use, forest fire, and illegal logging drastically decreased the area of dipterocarpaceae forest and its population. Decreased population and forest fragmentation could lead to extinction of the species because those 2 factors have important genetic consequence for the species survival in the area (Young et al. 1996; Buza et al. 2000; Finkeldey 2003). One consequence is the occurence of inbreeding which would increase homozigosity and mortality of the species due to lethal and semi-lethal alleles (Frankham 2005). This phenomenon, which is known as inbreeding depression, has been well documented on both flora and fauna (Frankham 2005). Other consequence is decreased genetic diversity due to loss of unique allele in a short period and may lead to total loss of allelic diversity caused by genetic drift in the long term (Lowe et al. 2005; Ng et al. 2008). The whole consequences will influence population fitness and increase the risk of extinction. International Union for Conservation of Nature and Natural Resources (IUCN) data (2010) showed that many flora were already on the brink of extinction as stated in the red list summary report. Some listed species in Indonesia are Shorea laevis and S. leprosula which have been categorized by IUCN as rare dipterocarp species with low risk and endangered (Ashton 1998). Study of shorea occurence from Sungai Lengkawi-Sungai Jengonoi forest compound in Sintang, West Kalimantan by Heriyanto and Subiandono (2003), underlined the rarity status of S. laevis.

In order to preserve effectively the above mentioned species, a conservation strategy incorporating their biology, i.e. reproductive biology and genetics, i.e. information on patterns of genetic variation and inbreeding status needs to be developed. Therefore, a study was conducted at a local scale with the objective to determine the rarity status of $S$. laevis and $S$. leprosula in relation with the IUCN report (2001) and 
their habitat characteristics, as basic information for their conservation strategy formulation as a part of forest management.

\section{Methods}

Field survey was undertaken in PT. Austral Byna concession area, which is located in Sungai Teweh-Sungai Lahai and Sungai Montalat-Sungai Sempirang forest areas, about $100 \mathrm{~km}$ from Muara Teweh, Central Kalimantan. Geographically, the forest area is laid between $0^{\circ} 30^{\prime}-1^{\circ} 68^{\prime}$ South Latitude and $114^{\circ} 45^{\prime}-115^{\circ} 45^{\prime}$ East Latitude. The whole concession area of PT. Austral Byna is 294,600 ha. Based on the forest status, the concession area of PT. Austral Byna is categorized into 3 forest classes i.e. production forest of 117,375 ha $(39.8 \%)$, limited production forest of 59,835 $(20.3 \%)$ ha, and conversion forest of 117,390 ha $(39.9 \%)$. The surveyed area for the present study includes production, limited production forests as well as conversion forest. The forest area is located at $150-550 \mathrm{~m}$ asl. The topography varies from plain land to hill with slope ranging from 5-45\%.

Data collection were conducted in 3 different ecosystem types, i.e. (1) virgin forest (VF)/KPPN, (2) secondary forest (SF), and (3) fragmented forest (FrF). Survey method used comBynation of transect line and plot establishment (Kusmana 1997). Several different plots, i.e. size $20 \times 20 \mathrm{~m}$ for observation at tree level, size $10 \times 10 \mathrm{~m}$ for pole level, size $5 \times 5 \mathrm{~m}$ for sapling, and size $2 \times 2 \mathrm{~m}$ for seedling were established along the transect. Each transect line had $20 \mathrm{~m}$ width, $500 \mathrm{~m}$ length, and sometimes the plots were modified according to the field condition (Figure 1). The measured parameters included density which shows the number of individuals per hectare, frequency which indicates the regularity occurrence of the species in a stand area, and dominance which refers to space occupation of the species in a certain area. Important value index (IVI) was then calculated by adding the relative density (rD), relative frequency $(\mathrm{rF})$, and relative dominance $(\mathrm{rDo})$.

Soil samples from the study location were collected during the survey according to the method of De Leenher and De Boodt (1959) as explained in the Guidelines of Physical Soil Analysis (PPTA 1997). At first, all soil samples were air dried before further chemical analysis in the laboratory (Jackson 1958). The soil pH were measured by $\mathrm{pH}$ meter. Soil chemical properties, i.e. carbon and organic matter contents were determined by Walkley-Black method, total nitrogen by micro-Kjeldahl method, phosphorus by molybdate method using UV Spectrophotometer (Shimadzu $160 \mathrm{~A})$, sodium and potassium were measured by flame photometer, and calcium, copper, iron, magnesium, manganese, and zinc by Atomic Absorption Spectrophotometer (AAS). For physical soil analysis, undisturbed soil samples were taken using soil sample rings.

Data on vegetation were analyzed using the formula [1][3] to determine the dominant species which is a species having the highest important value index in a certain vegetation type (Soerianegara \& Indrawan 1985):

$$
\begin{aligned}
& r D(\%)=\frac{\text { Density of one species }}{\text { Density of all species }} \times 100 \% \\
& r F(\%)=\frac{\text { Frequency of one species }}{\text { Frequency of all species }} \times 100 \% \\
& r D o(\%)=\frac{\text { Dominance of one species }}{\text { Dominance of all species }} \times 100 \%
\end{aligned}
$$

Further analysis using a software Tree Diversity Analysis (Kindt \& Coe 2005) was conducted in order to find out specific ecological distance among different ecosystem types.

\section{Results and Discussion}

Rarity (scarcity) of S. laevis and S. leprosula International Union for Conservation of Nature and Natural Resources (IUCN) categorizes rare plant species into various categories, such as vulnerable, endangered, critically endangered, and low risk (IUCN 2001). Results of vegetation analysis in the study location showed that $S$. leprosula was still sufficient and was distributed in the 3 study plots, whereas S. laevis were found only in 2 study plots, namely SF and FrF. According to IUCN criteria, rarity (scarcity) of a species could be categorized into critically endangered (CR), endangered $(\mathrm{EN})$, vulnerable $(\mathrm{Vu})$, and low risk $(\mathrm{LR}) /$ not threatened (IUCN 2001; Heriyanto \& Subiandono 2003). One of the characteristics for CR was that if the trees surveyed were in the natural habitat, there was at least 50 individual adult trees in area as large as $10 \mathrm{~km}^{2}$ or one individual adult trees in area as large as 20 ha. The characteristic for EN was that if in the surveyed area in the natural habitat, there was at least 250 individual adult trees in area size of $500 \mathrm{~km}^{2}$ or one individual of adult tree in area size

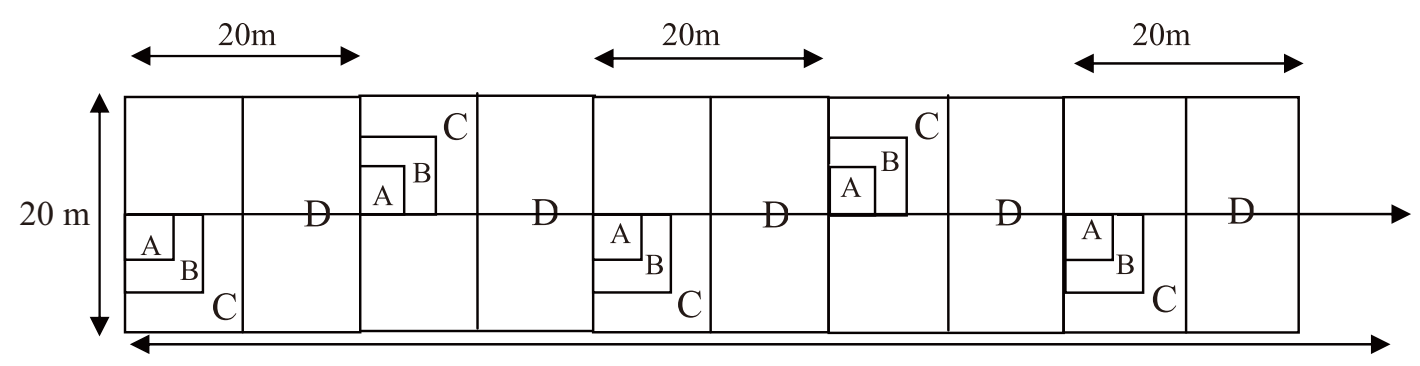

Figure 1 Lay out of transect line in the survey of vegetation analysis (Kusmana 1997). Observation plot for seedling $2 \times 2 \mathrm{~m}(\mathrm{~A})$, sapling $5 \times 5 \mathrm{~m}(\mathrm{~B})$, pole $10 \times 10 \mathrm{~m}(\mathrm{C})$, and tree $20 \times 20 \mathrm{~m}(\mathrm{D})$. 
of 200 ha. The characteristic for Vu was that if plants in the natural habitat were not categorized as critical and in the surveyed area there were at least 10,000 individual adult trees in area as large as $2,000 \mathrm{~km}^{2}$ or one individual tree in area of 200 ha. Category of LR was adopted if the situation did not belong to any of the rarity category as mentioned before.

On the basis of such criteria, by considering the density values of the 2 species, which for $S$. leprosula reached 5.51, 10.82, and 17.56 trees $^{-1}$ in VF, SF, and FrF respectively and S. laevis which showed value of 0.33 and 4.87 trees $^{-1}$ in SF and FrF (Table 1). It can be suggested that the species $S$. leprosula was not included in the criteria of $\mathrm{CR}, \mathrm{EN}$, or $\mathrm{Vu}$. In other words, the species could be categorized as LR in the areas of study location. The interesting phenomenon here was that in VF/KPPN the species of $S$. laevis was not found, so the consequence was that the species was categorized in the criteria of $\mathrm{CR}$, although the species occured in the two other ecosystem types. Therefore, particularly for S. laevis, in the ecosystem type of SF and FrF, the species was categorized as LR.

Analysis on regeneration development showed that $S$. leprosula seedlings up to pole stage were found in all three ecosystems. At pole stage in SF the species could be categorized as dominant species $(31.50 \%)$. On the other hand, presence of $S$. laevis regeneration was not dominant in SF and FrF (Table 2). In general, the presence of the two species did not play a significant role, either in the $\mathrm{VF} / \mathrm{KPPN}, \mathrm{SF}$ or FrF, except for pole stage of $S$. leprosula in FrF ecosystem. This phenomenon is similar with that in Sutisna report (1981) which suggested that a plant species could play some roles in an ecosystem if the IVI values for seedling and sapling stage reached 10 and $15 \%$, respectively.

$\mathrm{VF} / \mathrm{KPPN}$, is designated as conservation area with dense canopy and dominated by nondipterocarps species. The contribution of each dipterocarps species is less than $20 \%$, e.g. S. leprosula was $18 \%$, S. laevis was $5 \%$, and other dipterocarp species was $13 \%$. The seedling and sapling of $S$. leprosula and $S$. laevis were rare due to restricted penetration of the sunlight to reach the forest floor. The light intensity in the floor of VF, SF, and FrF was 242.72 lux, 434 lux, and 256 lux respectively. This difference made regeneration structure of those forests different.

Formerly, SF was logged-over area in 2008, is dominated by nondipterocarp species. However, some dipterocarp species was found, i.e. Dipterocarpus sp., S. leprosula, and $S$. laevis. FrF, formerly was logged-over in 1989 , is dominated by some dipterocarp species, such as $S$. leprosula and Dipterocarpus sp.

It is interesting to note that the virgin forest had lower number of saplings (817 individual ha ${ }^{-1}$ ) as compared to SF and FrF which had 1,630 and 952 individual ha $^{-1}$, respectively. The different composition of understory species was the result of different gap opening found among those forests. The densities of poles and trees were relatively similar in all plots. The establishment of saplings and poles might cause changes in the environment due to shading and in turn influences soil biological processes. The different shading also influences forest dynamics via their selective action on seedlings recruitment of $S$. leprosula and $S$. laevis.

Table 1 Important value indexes of rare plant species of tree stage in study areas

\begin{tabular}{llccccccc}
\hline Ecosistem type & Species name & Density & $\begin{array}{c}\text { Relative } \\
\text { density }\end{array}$ & Frequency & $\begin{array}{c}\text { Relative } \\
\text { frequency }\end{array}$ & Density & $\begin{array}{c}\text { Relative } \\
\text { density }\end{array}$ & IVI \\
\hline Virgin forest/KPPN & $\begin{array}{l}\text { Rarity species } \\
\text { S. leprosula }\end{array}$ & 10.82 & 6.26 & 0.64 & 5.16 & 1.64 & 7.41 & 18.84 \\
& S. laevis & - & - & - & - & - & - & - \\
\hline Secondary forest & Rarity species & & & & & & & \\
& S. leprosula & 5.51 & 4.72 & 0.37 & 3.86 & 1.19 & 8.25 & 16.83 \\
& S. laevis & 4.87 & 4.16 & 0.29 & 3.08 & 0.31 & 2.34 & 9.60 \\
\hline Fragmented forest & Rarity species & & & & & & & \\
& S. leprosula & 17.56 & 12.59 & 0.80 & 6.75 & 1.84 & 12.27 & 31.61 \\
& S. laevis & 0.33 & 0.24 & 0.04 & 0.33 & 0.05 & 0.33 & 0.91 \\
\hline IVI: impor
\end{tabular}

IVI: important value index

Table 2 Important value indexes of regeneration of rare plant species in the study areas

\begin{tabular}{|c|c|c|c|c|}
\hline \multirow{2}{*}{ Ecosystem type } & \multirow{2}{*}{ Species name } & \multicolumn{3}{|c|}{ Important value index $(\%)$} \\
\hline & & Seedling & Sapling & Pole \\
\hline \multirow[t]{3}{*}{ Virgin forest/KPPN } & Rarity species & & & \\
\hline & S. leprosula & 4.85 & 1.44 & 7.69 \\
\hline & S. laevis & - & - & - \\
\hline \multirow[t]{3}{*}{ Secondary forest } & Rarity species & & & \\
\hline & S. leprosula & 4.34 & 5.64 & 3.10 \\
\hline & S. laevis & 1.45 & - & 3.89 \\
\hline \multirow[t]{3}{*}{ Fragmented forest } & Rarity species & & & \\
\hline & S. leprosula & 8.34 & 2.26 & 31.50 \\
\hline & S. laevis & 1.11 & 1.13 & 3.68 \\
\hline
\end{tabular}


Edaphic characteristics of $S$. laevis and $S$. Leprosula habitat Presence of a plant species in an ecosystem was determined by various factors, both genetically and envrionmentally (Kozlowsky \& Pallardy 1997). Environmental factors which influence very much the plant growth and distribution, are edaphic and climatic factors. Results of soil chemical analysis, which comprises variables $\mathrm{pH}$, total N, C organic content, and total base cation in the 3 types of ecosystem (Figure 2) showed no significant differences among the ecosystem types. All plots showed low content of $\mathrm{N}$ and $\mathrm{C}$ which indicated that forest disturbance which led to secondary and fragmented forest does not affect $\mathrm{N}$ and $\mathrm{C}$ status in the soil. The same phenomenon was also observed in other soil variables. Although phosphorus constituted the other main nutrient needed by plants, besides the nitrogen, in acid soil with low $\mathrm{pH}$, element $\mathrm{P}$ was less available due to fixation by some forms of $\mathrm{Al}$ and $\mathrm{Fe}$ in the soil. $\mathrm{P}$ content in all plots were categorized as low in top soil and in subsoil which ranged between 2,33-4.90 ppm. The Ca content in all plots were also low, while $\mathrm{Mg}$ and $\mathrm{K}$ were moderate. The study area has low cation exchange capasity (CEC) and the values ranged
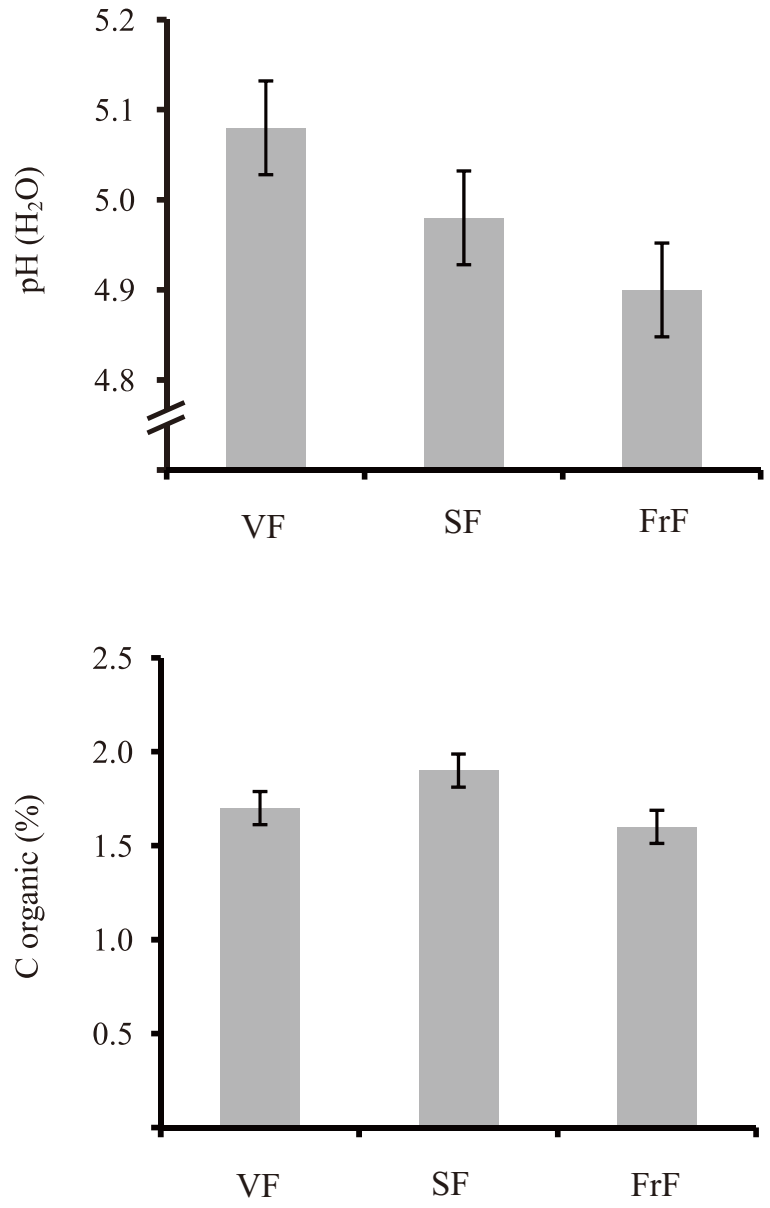

Figure 2 Several soil chemical properties in the study areas. between $8.48-10.51 \mathrm{me} 100^{-1} \mathrm{~g}$ of soil. However, the percentage of $\mathrm{Ca}, \mathrm{Mg}, \mathrm{K}$, and $\mathrm{Na}$ cations which occupied the collloidal surface (adsorption surface) on the average showed moderate level.

The above data showed that soil chemical properties in the study area was relatively homogeneous (Figure 2) and it was unlikely to contribute to the absence of $S$. laevis in the primary forest. Matthew et al. (2002) demonstrated that there were few significant correlations between edaphic soil mineral variables and physiographic variables on floristic similarity between plot study. However, there is only a consistent, but unexplained negative correlation of $\mathrm{Mg}$ with ridges versus slopes. Thus, differences between physiographic and edaphic effects can be compared without concern on autocorrelation. The results of the Mantel analysis at individual sites clearly illustrated that edaphic factors were much more important than physiographic factors in explaining floristic similarity between plots (Figure 4 and Figure 5). The exception to this rule is the Raya Hill $(\mathrm{H})$ plots, where the strength of physiographic effects $(0.242)$ are stronger than edaphic effects (20.011).
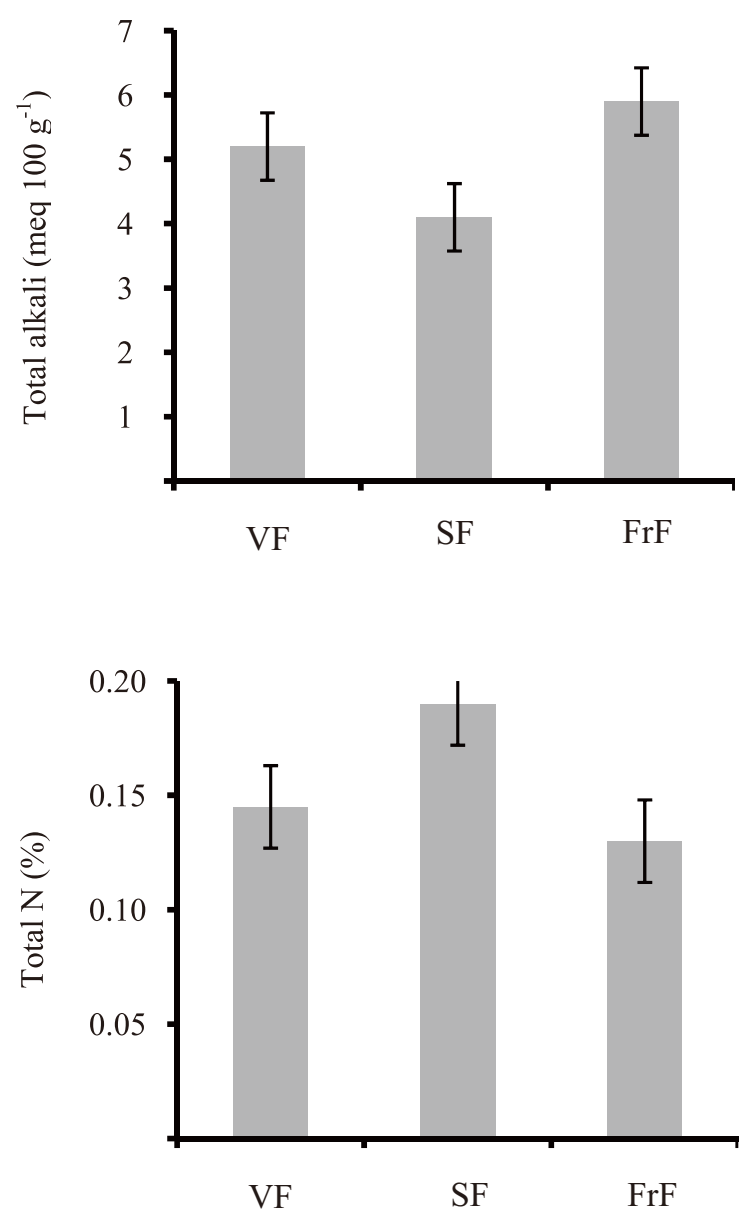
Water and oxygen could become the limiting factor for plant growth and distribution (Etherington 1976). Each plant species has different respond toward the availability of water and oxygen. Availability of water and oxygen in the soil are related with soil porosity and soil permeability. Analysis results of several soil physical properties in the study location (Figure 3) showed that density and porosity in the three types of ecosystem did not show significant differences. However, permeability in PF plot were categorized as low as compared with permeability in SF and in FrF.

Soil with low permeablity retards water infiltration to the soil (Zakaria et al. 2003). The consequence was that if rainfall is high, there would be waterlogging and soil oxygen will be reduced due to occupation of soil pores by water. Climate condition in the study location was categorized as climatic type A, based on Schmidt and Ferguson classification, with average rainfall of $2,195 \mathrm{~mm} \mathrm{year}^{-1}$, without any presence of dry months, and average number or raindays of 17 days (Stasiun Bandar Beringin, Muara Teweh, 1992-2002). Tree species which are sensitive toward waterlogging would not grow in soil with low permeability. From the study of natural distribution of $S$. laevis and $S$. leprosula, it was known that $S$. laevis grows well in hill slopes, whereas $S$. leprosula grows well in hill valley (Ashton 1982; MoF 2002). This phenomena showed that S. laevis requires soil condition with considerably good permeability, therefore this species occupies hill slopes. The topography of VF ecosystem was considered as plain while those at the two other ecosytem types ranged from plain land to hill. Results of this study showed that in VF, S. laevis were not found and this was in conformity with the low permeability of the soil in the plot (Figure 4).

Analysis of species diversity The existence of a species is often affected by presence of other species in that habitat. The
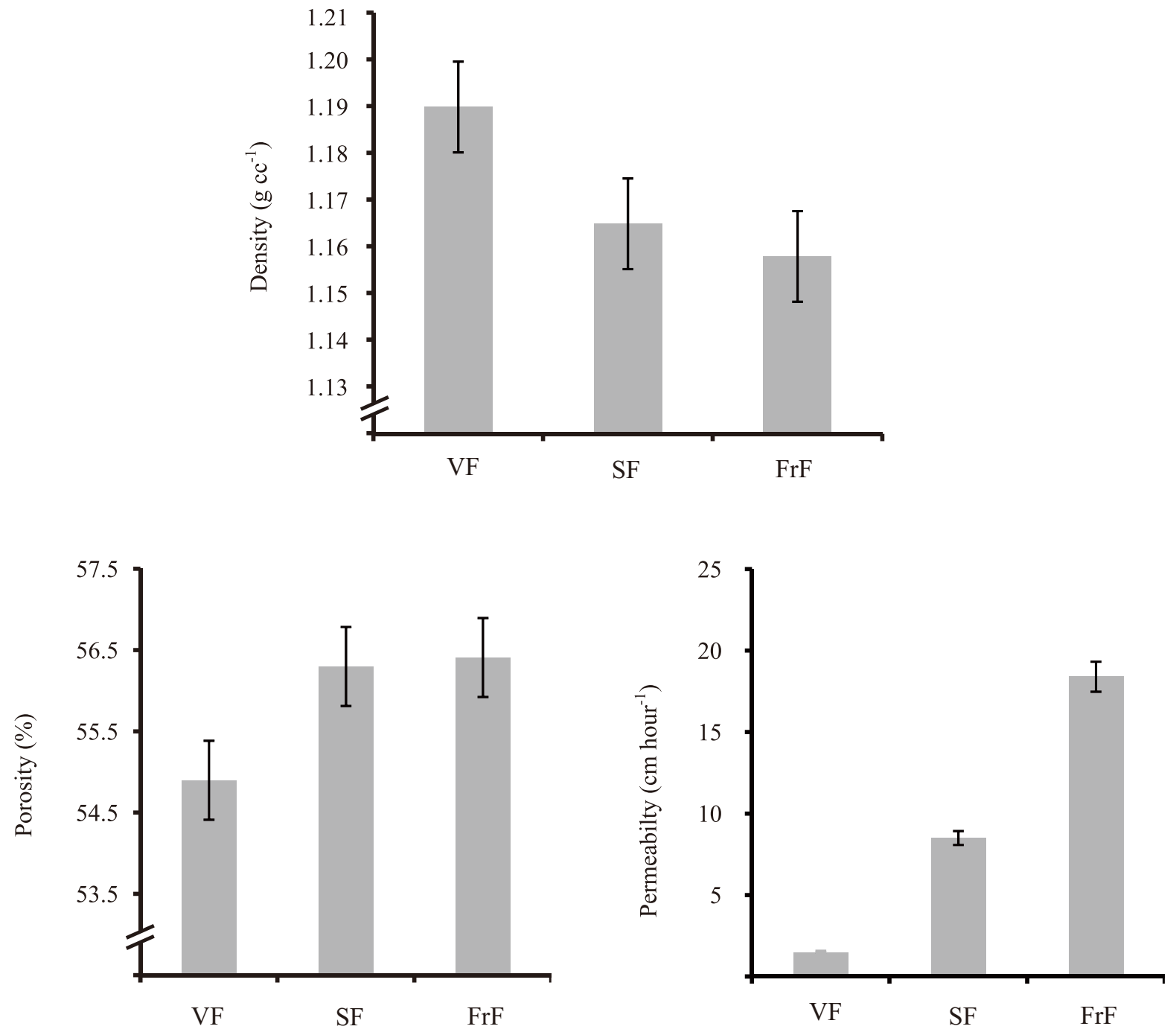

Figure 3 Several soil physical properties in the study areas. 
competitive exclusion principle states that given a suite of species, interspecific competition will result in the exclusion of all but one species (Stoll \& Newbery 2005). This is particularly true if there is little or no temporal and spatial variation in the environment and the species are ecologically similar. Tree diversity analysis (Kindt \& Coe 2005) showed that each type of ecosytem or study plot had different characteristic, or in other words, the ecological distance between study plots were far from each other (Figure 4 and Figure 5). Several species had large variability or had varying density values in each study plot, such as $S$. laevis, Dipterocarpus sp., Shorea sp., Dipterocarpus ibmalatus, Palaquium rostatum, and Quercus bennettii. Presence of $S$. laevis in the SF plot was followed by the appearance of such species as $S$. uliginosa, Dialium platysepalum, D. ibmalatus, P. rostatum, Vatica rasak, Adinandra sp., and Memecyclon steenis. On the other hand, for $S$. leprosula, other species which followed its presence (positively correlated) were $S$. kunstleri, Castanopsis sp., Shorea sp., Quercus bennettii, Diospyros sp., and D. hasseltii.

Figure 5 showed that at seedling stage, each study plot had different characteristics. S. laevis possessed the highest abundance in study plot of SF. This species had positive correlation with species of Dysoxylum sp and Sindora beccariana. Presence of $S$. leprosula had some relation with the appearance of species M. steenis, Dillenia foetida, Alseodaphna sp., and Polythia glauca.

Previous study by Stoll and Newbery (2005) showed that small trees $(10-100 \mathrm{~cm} \mathrm{dbh})$ growth is suppressed by adult trees of the same species as neighbors. They proposed that the large trees drain resources from the smaller trees via mycelial networks because most of the large dipterocarps are still growing fast as the forest has not yet reached its expected maximum basal area for the site. Although carbon is probably at a premium for small trees in the understory and they gain it partly from the larger trees, large trees may take phosphorus from the smaller ones and thus slow their growth. To acquire phosphorus, mycorrhizae allow the large trees to expand their root systems by connecting with and using the smaller trees (Finlay 2008).

\section{Conclusion}

The study reveals that, edaphic factors especialy soil permeability, low rate of seedling establishment, inability of seedlings to compete with other plants collectively contributed to the occurrence of a small population of $S$. laevis in the study areas, and the interplay of all these factors might have led to the "low risk" status of this species in those type of ecosystem. Further studies on genetic and ecophysiology, including the role of ectomycorrhizae are needed in order to make a conservation program formulation completely.

\section{Acknowledgements}

This research was supported by Ministry of National Education of Republic of Indonesia through the competitive

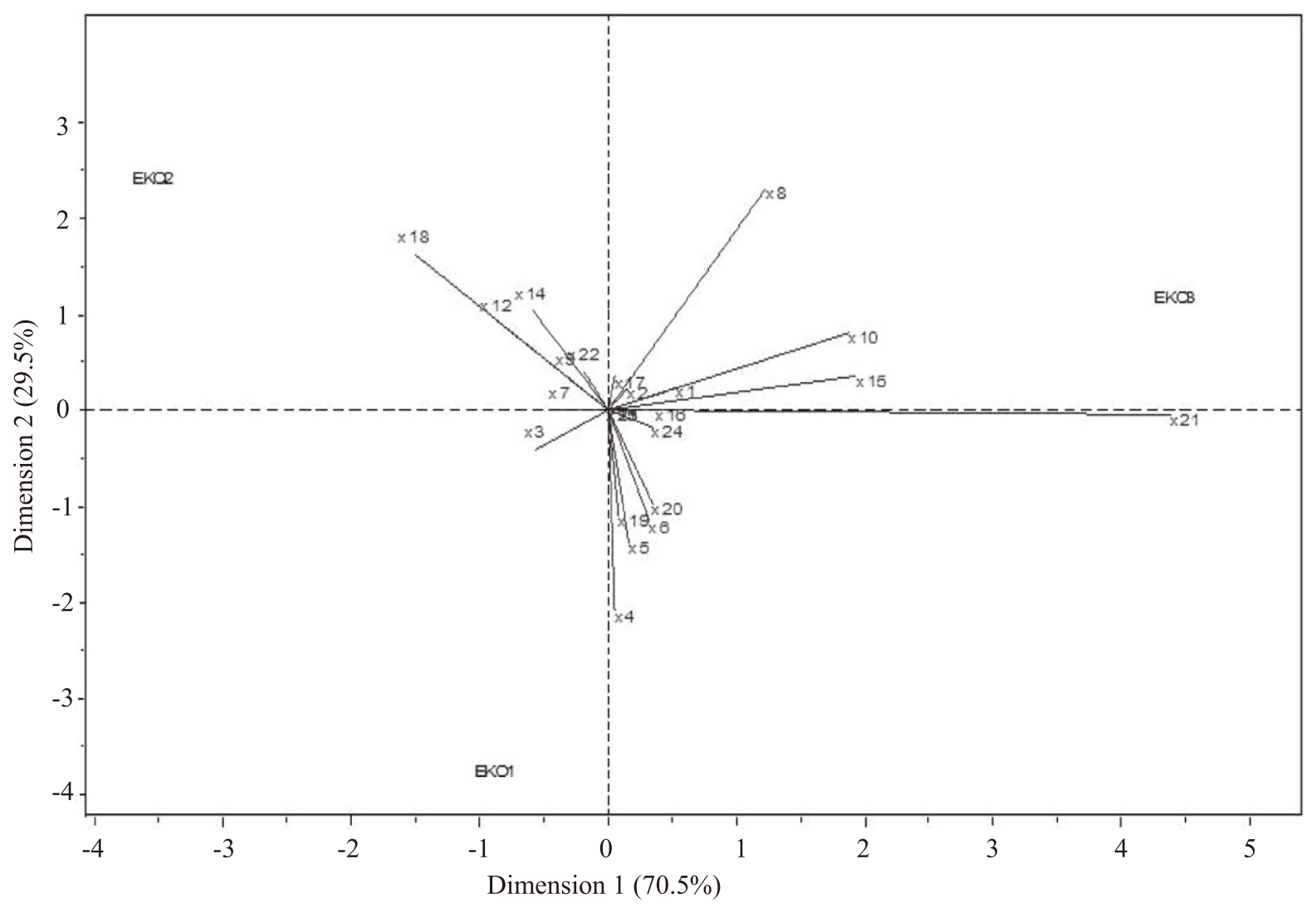

Figure 4 Analysis of species diversity of tree stage in the study areas. 


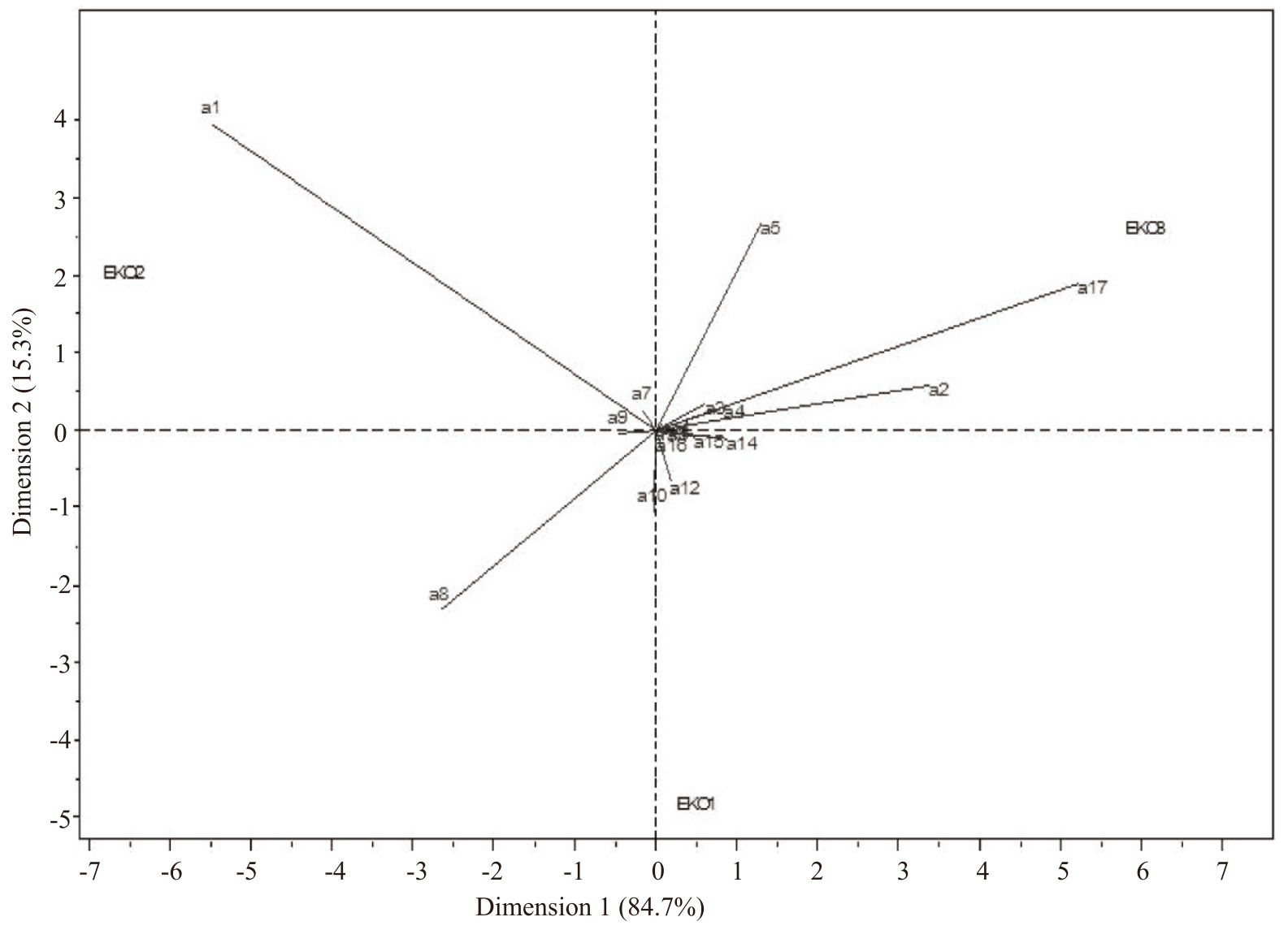

Figure 5 Analysis of species diversity of seedling stage in the study areas.

research grant No: 688/SP2H/PP/DP2M/X/2009. To the Management and Staff of PT. Austral Byna for supporting the research are gratefully acknowledged.

\section{References}

Ashton PS. 1982. Dipterocarpaceae. Flora Malesiana 1(9):237-552.

Ashton PS. 1998a. Shorea laevis. In: IUCN Red List of Threatened Species. Version 2009.2.

Ashton PS. 1998b. Shorea leprosula. In: IUCN Red List of Threatened Species. Version 2009.2.

Buza L, Young A, Thrall P. 2000. Genetic erosion, inbreeding and reduced fitness in fragmented populations of the endangered tetraploid pea Swainsona recta. Biological Conservation 93:177-186.

De Leenheer L, De Boodt M. 1959. Determination of aggregate stability by the change in mean weight diameter. In: Proceedings of the International Symposium on Soil Structure. Ghent, Belgie. Rijkslandouwhogeschool.pp290-300.

Etherington JR. 1976. Environment and Plant Ecology. New Delhi: Wiley Eastern Limited.
Finkeldey R. 2003. An Introduction to Tropical Forest Genetics. Gottingen: Institute of Forest Genetics and Forest Tree Breeding.

Finlay RD. 2008. Ecological aspects of mycorrhizal symbiosis: with special emphasis on the functional diversity of interactions involving the extraradical mycelium. Journal Experimental Botany 59(5):11151126. http://dx.doi.org/10.1093/jxb/ern059.

Frankham R. 2005. Genetic and extinction. Biological Conservation 126:131-140.

Heriyanto NM, Subandiono E. 2003. Rarity status of trees species in Lekawi-Jengoni River Compound, Sintang, West Borneo. Buletin Plasma Nutfah 9(2):28-37.

[IUCN] International Union for Conservation of Nature and Natural Resources. 2001. IUCN Red List Catagories and Criteria version 3.1. Switzerland: IUCN Species Survival Commission.

Jackson ML. 1958. Soil Chemical Analysis. New Delhi: Prentice Hall of India.

Kindt R, Coe R. 2005. Tree Diversity Analysis: A Manual and Software for Common Statistical Methods for Ecological and Biodiversity Studies. World Agroforestry Centre 
(ICRAF). Nairobi: ICRAF.

Kozlowski TT, Pallardy SG. 1997. Physiology of Woody Plants, Second edition. New York: Academic Press.

Kusmana C. 1997. Vegetation Survey Method. Bogor: IPB Press.

Lowe AJ, Boshier D, Ward M, Bacles CFE, Navvaro C. 2005. Genetic resource impacts of habitat loss and degradation; reconciling empirical evidence and predicted theory for neotropical trees. Heredity 95:255273. http://dx.doi.org/10.1038/sj.hdy. 6800725 .

Matthew DP, Ashton PS, Kaufman LS, Plotkin JB. 2002. Habitat patterns in tropical rain forest: a comparison of 105 plots in Northwest Borneo. Ecology 83(10):27822797.

[MoF] Ministry of Forestry of Republic of Indonesia. 2002. Shorea leprosula Miq. Short Seed Information No. 28. www.dephut.go.id/INFORMASI/RRL/IFSP/Shorea_L eprosula.pdf[08 December 2009].

Ng KKS, Lee SL, Ueno S. 2008. Impact of selective logging on genetic diversity of two tropical tree species with contrasting breeding systems using direct comparison and simulation methods. Forest Ecology and Management 257:107-116.

Purwaningsih. 2004. Ecological distribution of dipterocarpaceae species in Indonesia. Biodiversitas
5(2):89-95.

[PPTA] Pusat Penelitian Tanah dan Agroklimat. 1997. Soil Map of Borneo Island. Bogor: Pusat Penelitian Tanah dan Agroklimat.

Soerianegara I, Indrawan A. 1985. Indonesian Forest Ecology. Bogor: IPB Press.

Stoll P, Newberry DM. 2005. Evidence of species specifict neighborhood effects in the Dipterocarpaceae of a Bornean Rain Forest. Ecology 86(11):3048-3062.

Sukardjo S, Hagiahara A, Yamakura T, Ogawa H. 1990. Floristic composition of a tropical rain forest in Indonesia Borneo. Bulletin of the Nagoya University Forest 10:1-44.

Sutisna U. 1981. Tree Species Composition of a Logged-over at Batulicin, South Kalimantan: Description and Analysis. Bogor: Balai Penelitian dan Pengembangan Kehutanan, Badan Penelitian dan Pengembangan Pertanian.

Young A, Boyle T, Brown T. 1996. The population genetic consequences of habitat fragmentation for plants. Trends in Ecology and Evolution 11:413-418.

Zakaria NA, Ghani AA, Abdullah R, Sidek LM, Ainan A. 2003. Bioecological drainage system (BIOECODS) for water quality and quantity control. International Journal of River Basin Management 1(3):237-251. 